Acta vet. scand. $1986,27,326-342$.

From the National Veterinary Institute, Uppsala, Sweden.

\title{
NERVOUS TISSUE LESIONS CAUSED BY ELAPHOSTRONGYLOSIS IN WILD SWEDISH MOOSE
}

\author{
By \\ Margareta Steen and Claes Rehbinder
}

\begin{abstract}
STEEN, MARGARETA and CLAES REHBINDER: Nervous tissue lesions caused by elaphostrongylosis in wild Swedish moose. Acta vet. scand. 1986, 27, 326-342. - During the first 5 months of 1985,35 moose were obtained for necropsy at the National Veterinary Institute, Uppsala, Sweden. 17 (49\%) of these cases were found to be infected with Elaphostrongylus sp. The nematodes were found in the epidural space of the spinal cord and brain, around and in the sciatic nerves and in muscle fasciae. Predilection sites appeared to be near cauda equina and the fasciae of the thoracic, gracilis and sartorius muscles. Most of the infected animals were calves. Both sexes were equally represented. Pathological changes found were characterized by focal haemorrhages and oedema. The changes were present in the muscle fasciae and in the leptomeninges of the brain and spinal cord. Beside infiltrates of mainly lymphocytes and plasma cells, adult nematodes, larvae and eggs were observed.

Cases with mild gliosis in the cerebrum and degenerative changes of peripheral nerve roots affecting the epi- and perineurium were also found. In one case the inflammatory changes reached the endoneurium of a sciatic nerve bundle and in another case into a ganglion.

Inflammatory reactions against the parasite were mainly directed towards eggs. In loose connective tissue close to nerve tissue in the central nervous system larvae were found close to eggs and remains of eggs indicating that eggs may hatch at this site.

This investigation shows that natural infections with Elaphostrongylus sp. occur in wild moose and may produce pathological changes in large peripheral nerves and in the central nervous system.
\end{abstract}

moose; elaphostrongylus; nematode; nervous les ion.

In April 1984 a 10-month-old moose calf found dead, was submitted for necropsy at the National Veterinary Institute, Uppsala, Sweden. At necropsy the calf was emaciated and several Elaphostrongylus sp. were found in the epidural space of the spinal cord but also in muscle fasciae. 
During the first five months of 1985 moose from several localities in the middle and northern parts of Sweden were reported dead, their total number exceeding 200. Most of the dead animals were found within a few rather limited areas. In addition most of the dead animals were calves.

\section{MATERIAL AND METHODS}

During winter and spring 1985 carcasses of 35 moose were obtained. The material comprised both sexes and different age groups (Table 1).

At necropsy the brain was removed and the spinal cord was exposed along its whole length and removed. The sciatic nerves were dissected free and the muscle-bundles of the whole body were macroscopically examined.

Macroscopically affected areas of the brain, spinal cord, sciatic nerves and muscle fasciae were fixed in $10 \%$ formalin after being examined for the presence of parasites.

After fixation tissues were embedded in paraffin, sectioned $4 \mu \mathrm{m}$ and stained with haematoxylin eosin and v. Gieson.

For measuring adult nematodes were placed in saline on glass slides and mounted under cover-slips ringed by vaseline. 6 females and 2 males were measured.

Larvae from faeces and lungs were collected from 11 animals. They were investigated by means of Baermann technique. The larvae found were kept in water at $4^{\circ} \mathrm{C}$ and studied after they had been immobilized by mild heat and mounted under coverslips ringed by vaseline.

\section{RESULTS}

The necropsied moose represented both sexes, 11 males and 24 females. The nutritional state varied: 26 animals were emaciated, 1 was in a poor nutritional state, while 8 appeared to be in normal nutritional state (Table 1 ).

In 2 cases the necropsy was entirely negative. Emaciation without any signs of underlying disease was found in 1 case.

In $17(49 \%)$ of the 35 animals necropsied the only pathological changes found were due to elaphostrongylosis, defined to the finding of adult nematodes; out of these moose, 1 was in normal and 1 in moderate nutritional state while 15 animals were 


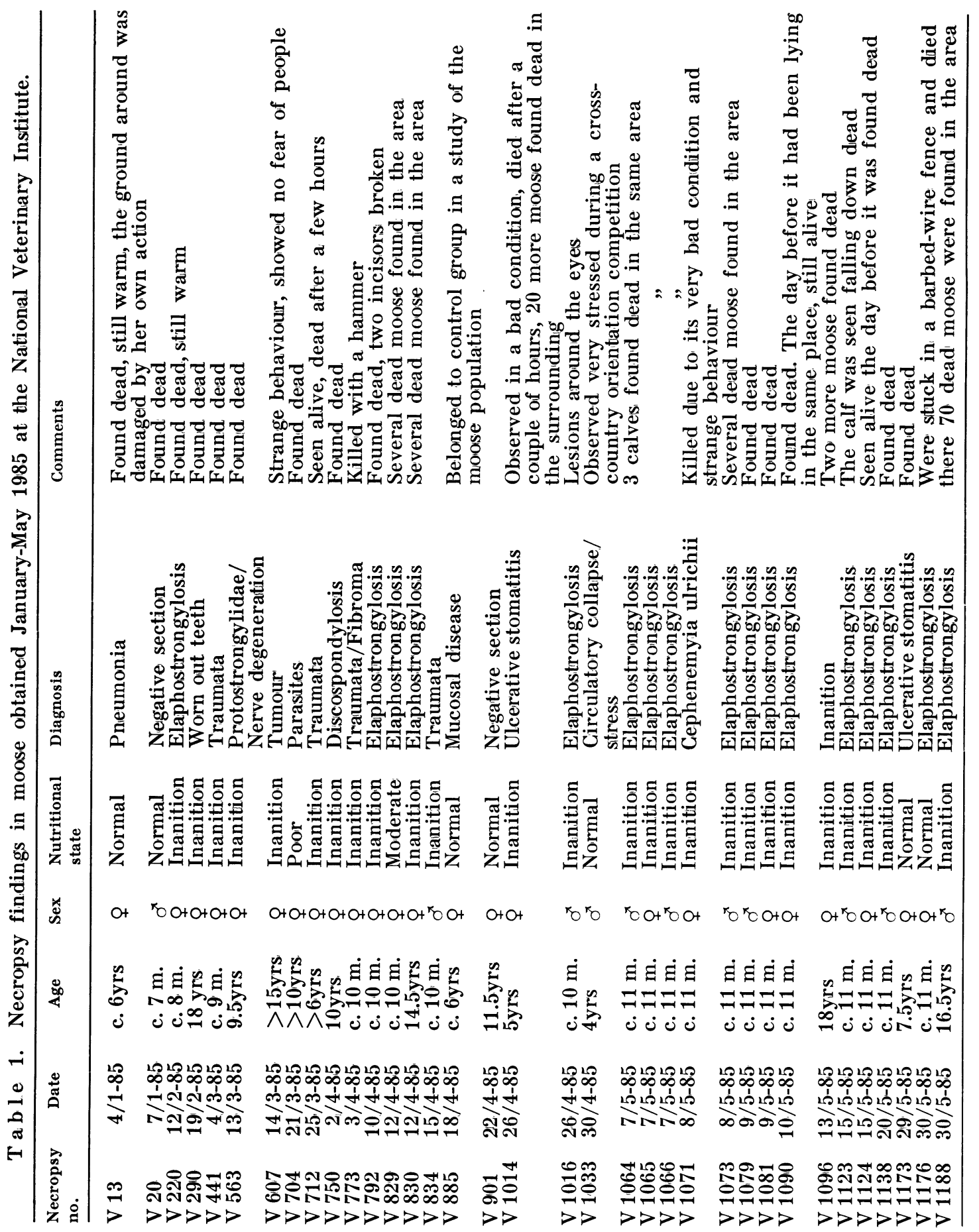




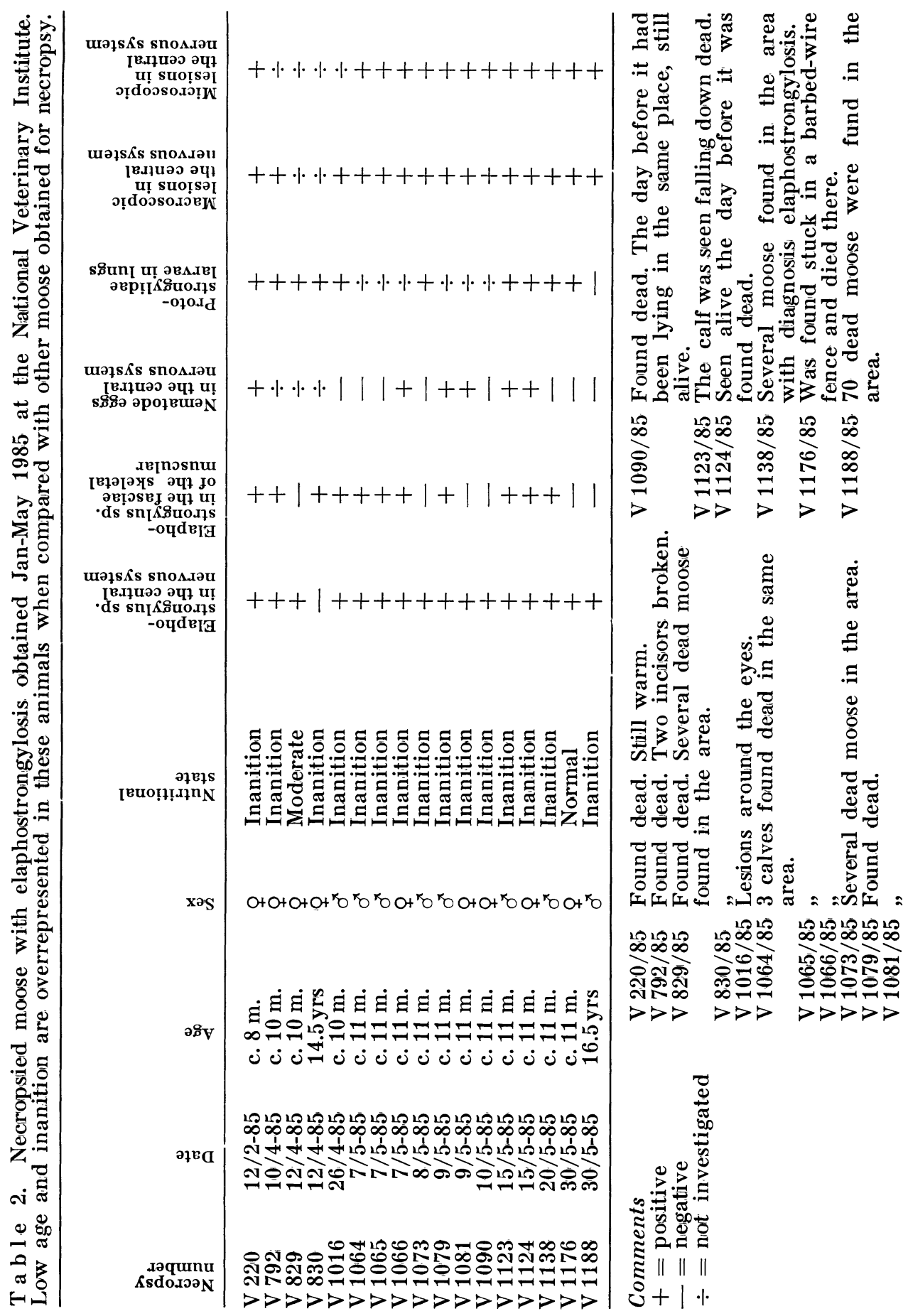


emaciated. For the remaining animals the cause of death could be related to other diseases or traumata.

It is notable that in the group of moose infected with Elaphostrongylus sp. emaciation and low age were overrepresented (Table 2).

\section{Gross pathology}

In each of the infestated 17 animals, $1-30$ adult Elaphostrongylus sp. were found. Adult nematodes were found in the central nervous system of 16 animals. In 11 of the examined moose, however, nematodes were found mainly on the fasciae between muscle bundles. Predilection sites appeared to be the fasciae of the superficial thoracic muscles and fasciae between the gracilis and sartorius muscles. The findings were usually associated with haemorrhages and oedema with a diameter of $1-2 \mathrm{~cm}$.

In the central nervous system most of the nematodes were found in the epidural space of the spinal cord laying mainly close to the Filum terminale (Fig. 1). In one case a single adult Elaphostrongylus sp. was found in the subdural space between the cerebrum and the cerebellum.

\section{Histology}

$\mathrm{N}$ e rvou s tis s ue. In the central nervous system inflammatory changes were regularly seen. Several cases showed focal inflammatory processes in the leptomeninges of the brain (Fig. 2). They were usually mild, characterized by infiltration of lymphocytes, plasmacells and macrophages. The macrophages often contained yellowish detritus masses resembling hemosiderin. In one animal an adult parasite was found in the subdural space of the cerebrum. It was surrounded by a mild infiltration of lymphocytes. Foci of mild gliosis of the cerebrum were present in 6 cases.

Furthermore, in 14 cases the leptomeninges of the spinal cord revealed focal inflammatory processes with marked infiltrations of lymphocytes, plasmacells and macrophages containing detritus. Present were also free yellowish granular detritus masses, oedema and haemorrhages.

The inflammatory changes in the meninges sometimes extended to the roots of the spinal nerves. In some areas mild 


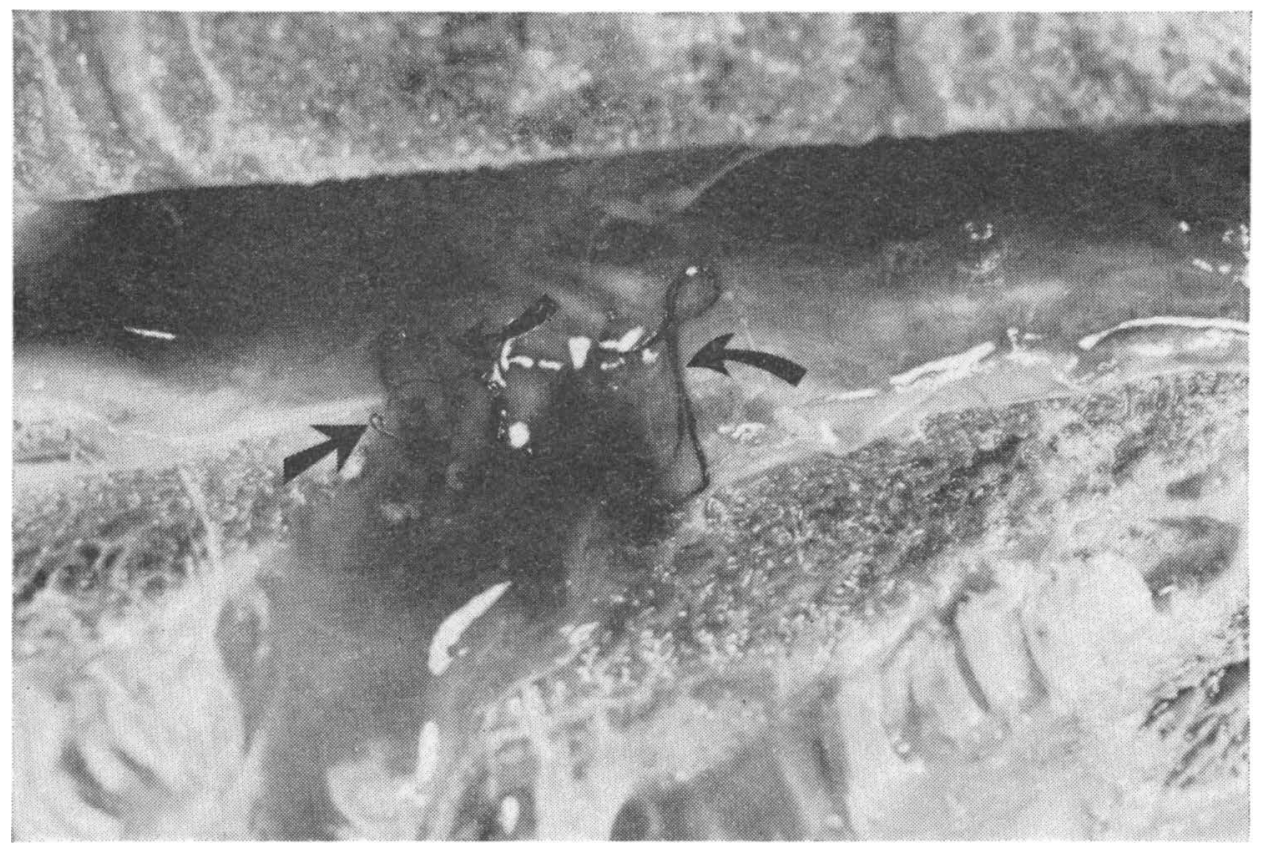

Fig u r e 1. Adult Elaphostrongylus sp. in the epidural space of the spinal cord close to a spinal nerve root (arrows). Note the haemorrhage.

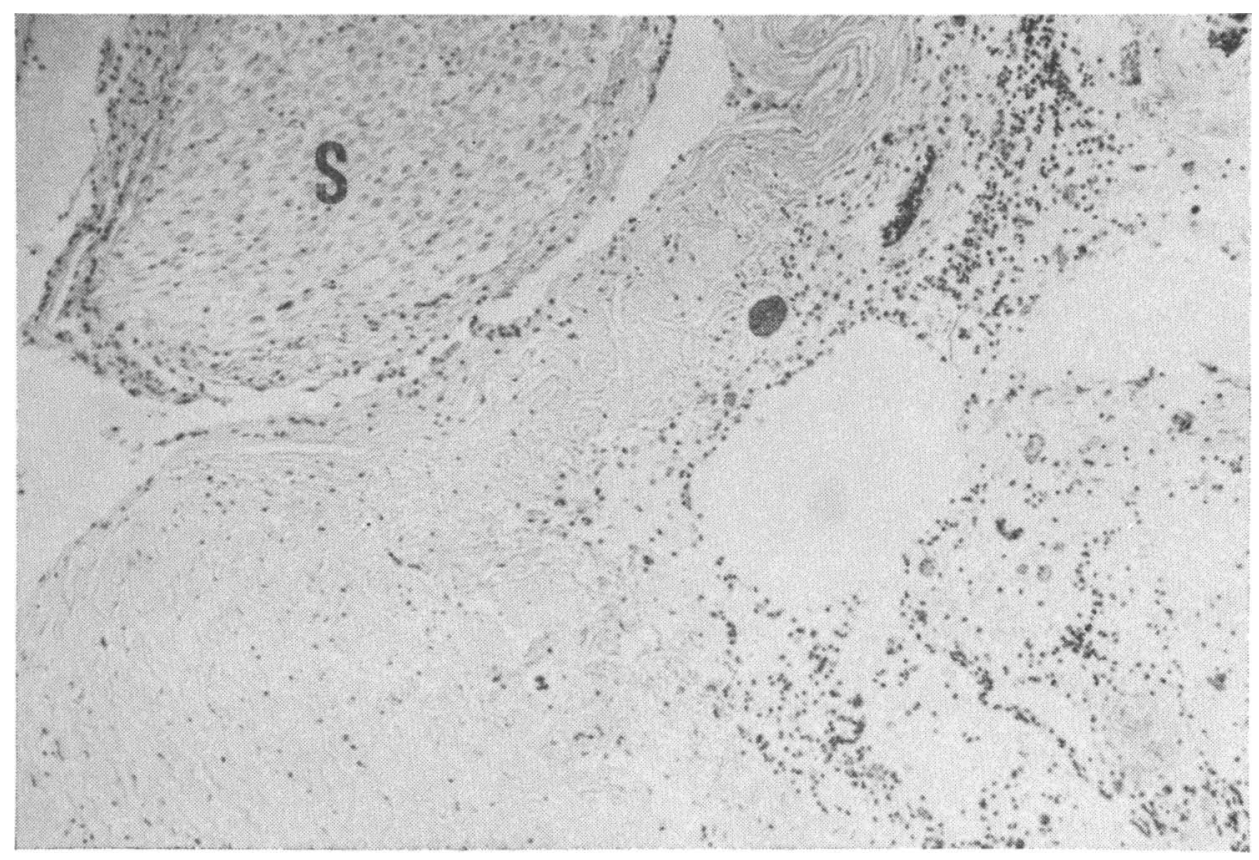

Figure 2. Inflammatory changes reaching the root of a spinal nerve $(\mathrm{S})$. HE $\times 35$. 


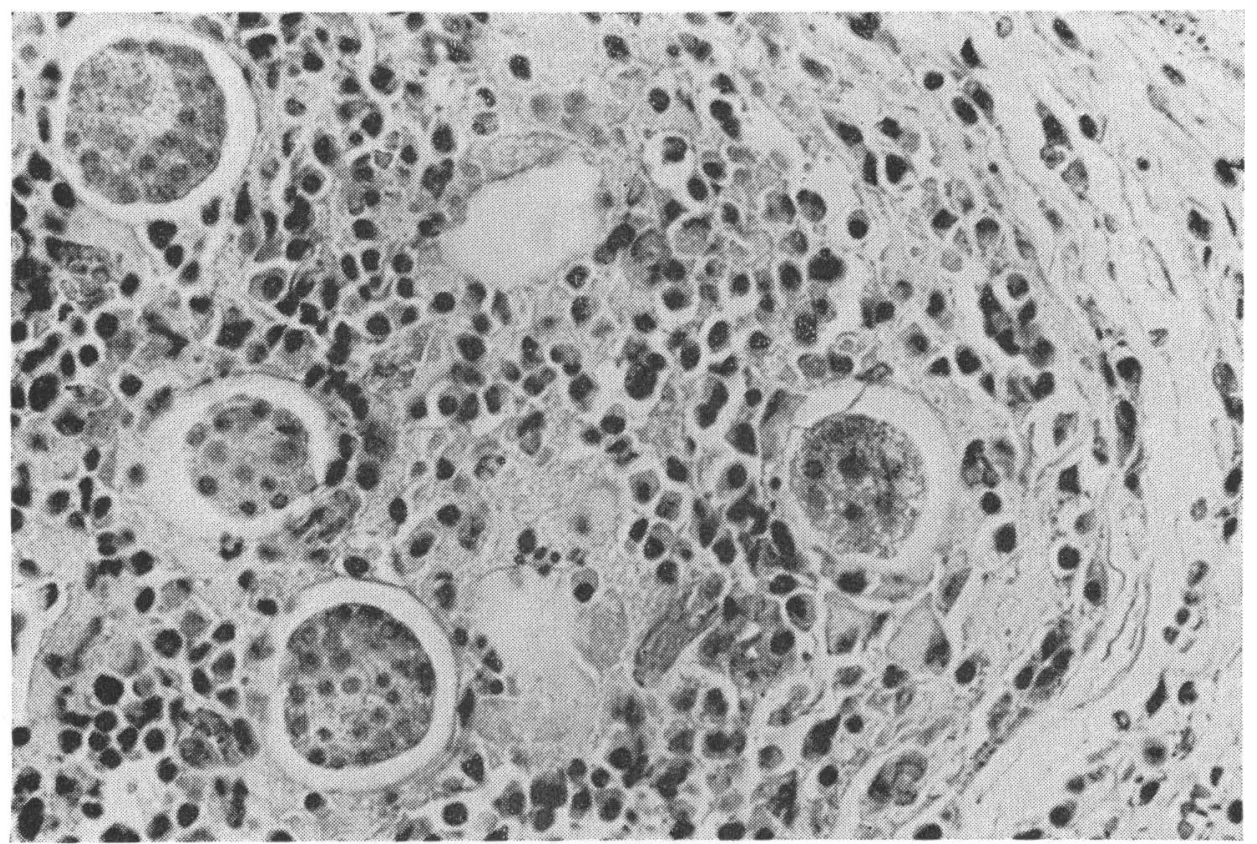

Figure 3. Egg granuloma. The granuloma is surrounded by a thin capsule of loose connective tissue. In the center eggs are present in vacuoles lined by a thin lamina and surrounded by mononuclear and epithelioid cells. $\mathrm{HE} \times 560$.

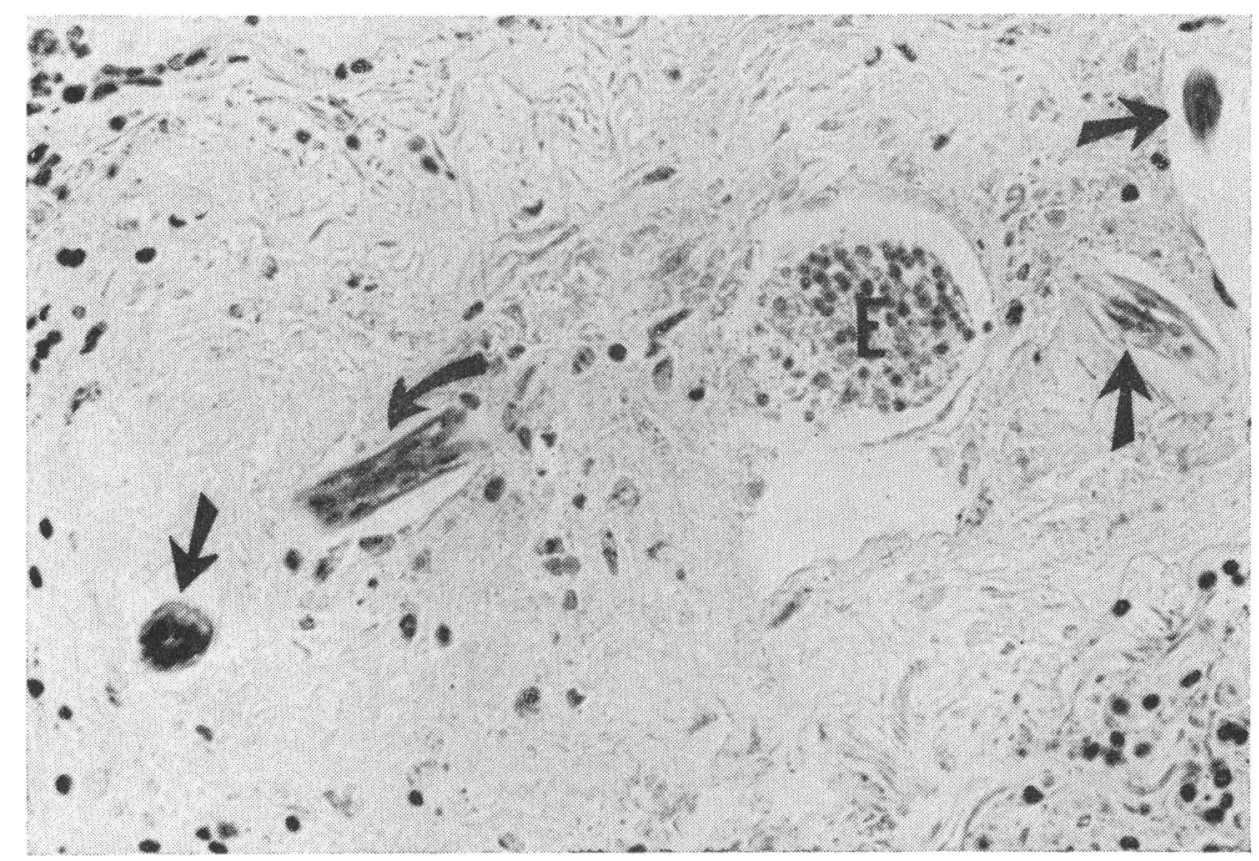

F ig u r e 4. Hatched larvae (arrows) close to an egg (E) granuloma. $\mathrm{HE} \times \mathbf{2 4 0}$. 


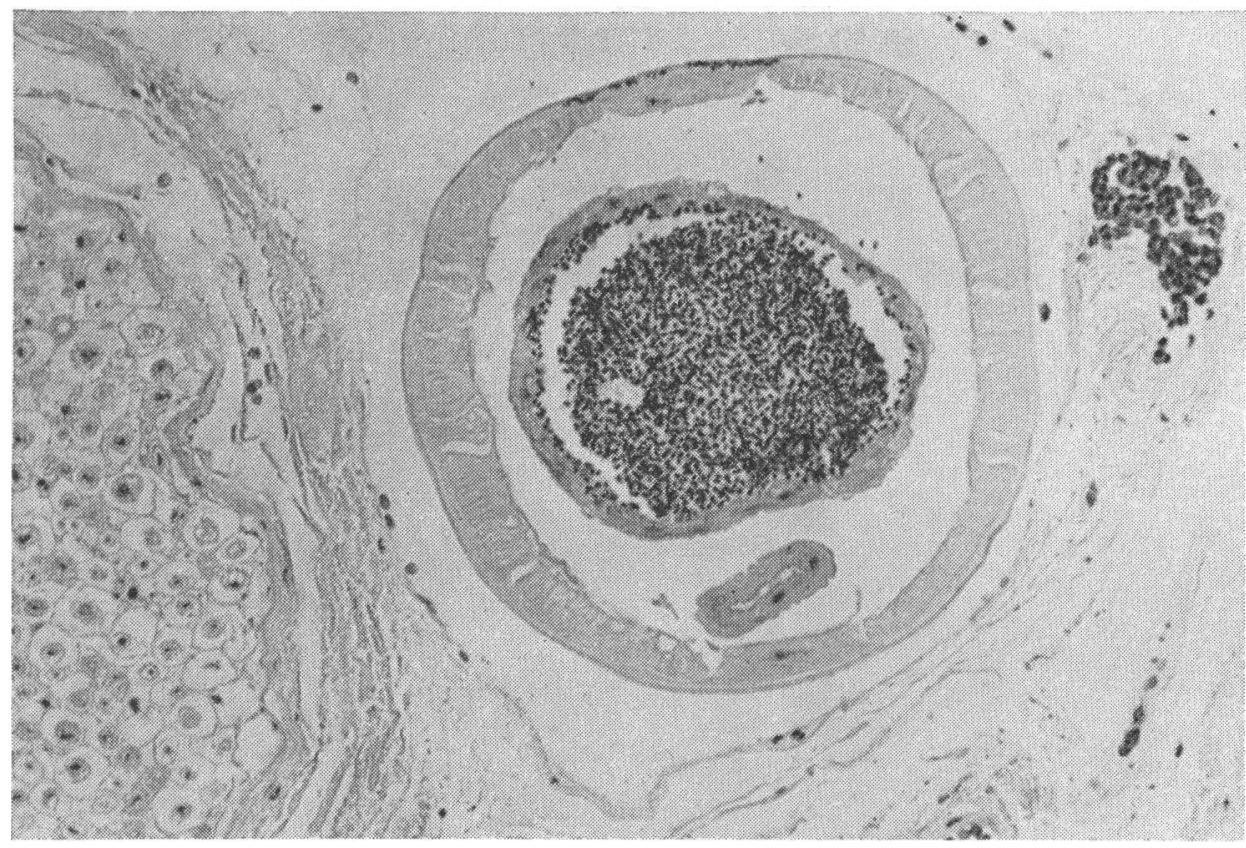

Figure 5. Cross section of an adult Elaphostrongylus sp. close to a nerve bundle. The inflammatory response is low. $\mathrm{HE} \times 240$.

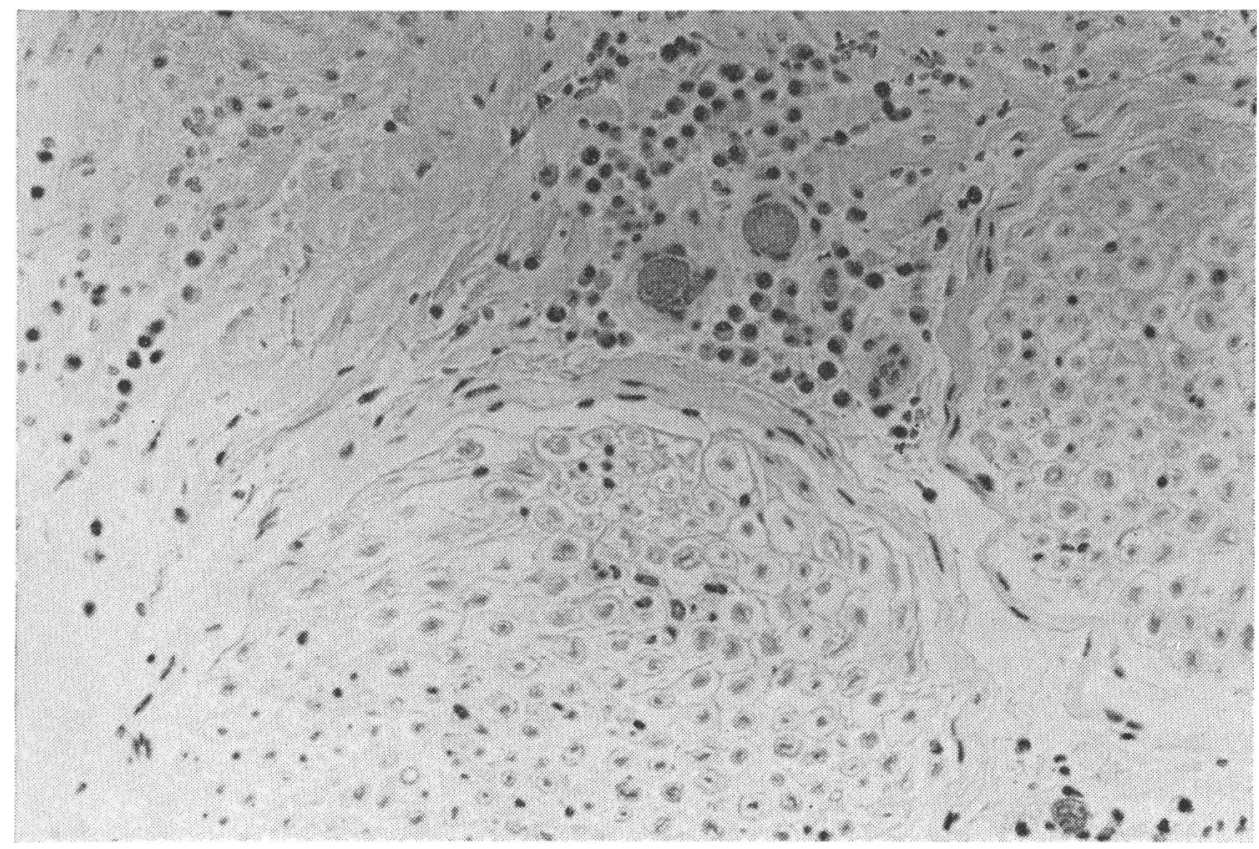

F i g u re 6. Diffuse infiltration of mononuclear cells extending into nerve tissue. The infiltration affects the epi-, peri- and endoneurium. Eggs are seen in the loose connective tissue between the nerve bundles. $\mathrm{HE} \times 240$. 


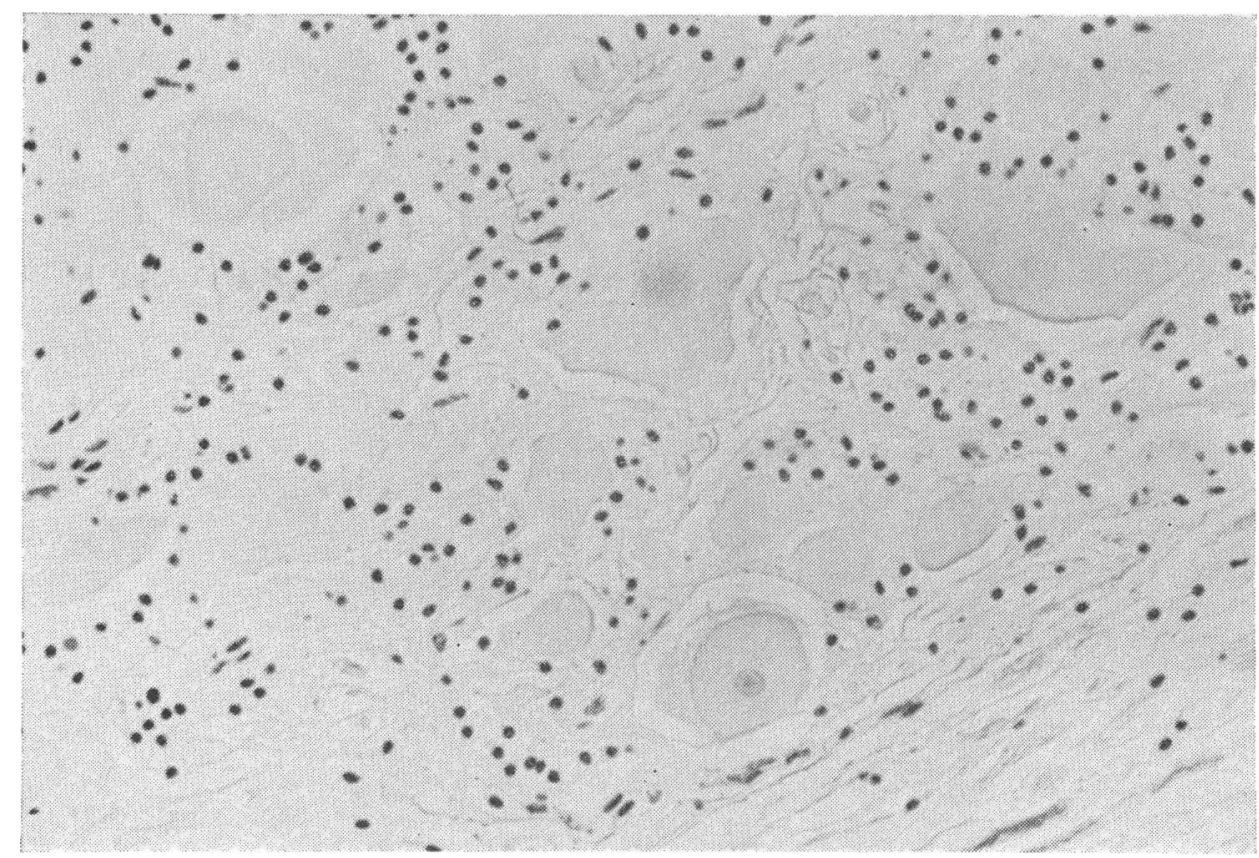

Figure 7. A nerve ganglion with diffuse infiltration of mononuclear cells. Ganglion cells are in a late stage of degeneration. $\mathrm{HE} \times 240$.

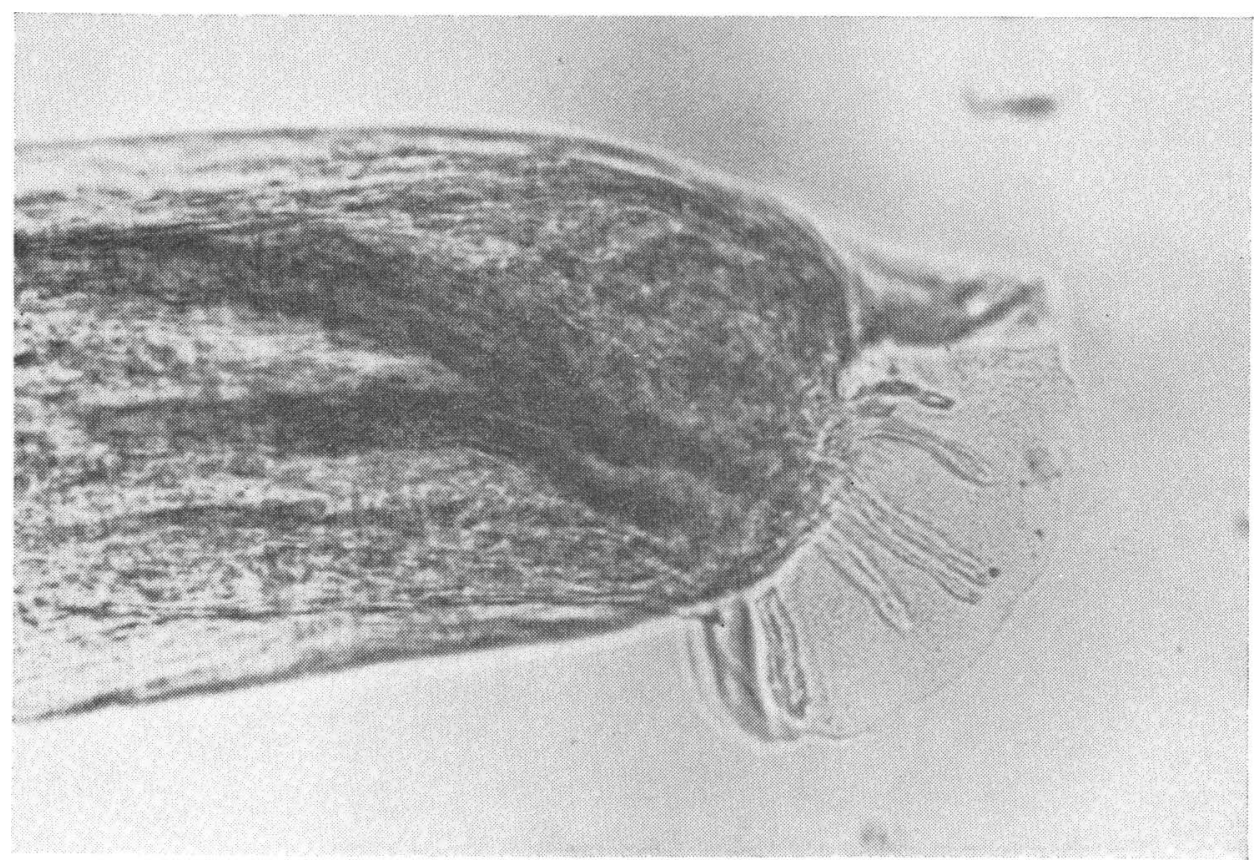

F ig u r e 8. Caudal end of an adult male of Elaphostrongylus sp. $\times 10$. 
degenerative changes with infiltration of lymphocytes were noticed (Fig. 3). In the area of Filum terminale, granuloma formations around eggs of Elaphostrongylus sp. were frequently found. The granulomas had a thin capsule of loose connective tissue. In the center of the granulomas, eggs, which were laying in clumps, were present in vacuoles lined by a thin lamina and surrounded by infiltrates of mainly lymphocytes, plasmacells and epithelioid cells (Fig. 4). In some granulomas hatched larvae and remains of eggs were detected (Fig. 5).

Also in the loose connective tissue between nerve bundles in the roots of spinal nerves, adults, larvae and eggs of Elaphostrongylus sp., and granulomas were observed. The location was mainly close to the roots of the sciatic nerves.

The inflammatory response towards adults and larvae of Elaphostrongylus sp. was usually none or mild (Figs. 5 and 6), whereas inflammatory reactions towards eggs were pronounced (Fig. 4).

Diffuse infiltration of the mononuclear cells was in some cases found to extend into nerve tissue affecting the epi-, periand endoneurium (Fig. 7). Similar changes were also found in one ganglion (Fig. 8).

Some of the lesions close to eggs and larvae gave the impression of a tunnel or track lined with inflammatory cells, bleedings and detritus masses.

$\mathrm{F}$ a s c i a e. In the fasciae, areas with a marked infiltration of lymphocytes, plasmacells and macrophages were regular findings. In these areas haemorrhages and numerous dilated capillaries were seen, but also granular, yellowish, hemosiderinlike detritus masses. The latter were to a large extent present in macrophages, but also laying free. Larvae and eggs of Elaphostrongylus sp. and tunnel-formations were sometimes found. Adults were not infrequently found in these areas.

\section{Parasitology}

Elaphostrongylus sp. The description of the adult nematode is based on a study of 2 male and 6 female specimens.

$\mathrm{M}$ a l e. Length 290 and $330 \mathrm{~mm}$. Width 0.190 and $0.240 \mathrm{~mm}$. Spiculae short and stout. In one the spiculae were of equal length, $0.175 \mathrm{~mm}$. In the other unequal 0.160 resp. $0.180 \mathrm{~mm}$. Bursa high 
developed, entire, $0.180 \mathrm{~mm}$ wide. Dorsal ray with a stout base, bifurcated into two, nearly parallel, branches.

F e m a le. Length $550-630 \mathrm{~mm}$. Width $0.250--0.260 \mathrm{~mm}$. Excretory pore $0.580-0.620 \mathrm{~mm}$ from anterior end. Vulva 0.190 $\mathrm{mm}$ and anus $0.050 \mathrm{~mm}$ from posterior end. Female tail tip bluntly conical. Provagina absent.

First-st a g l a rva e. Dorsal spine present.

Following classification keys by either Anderson (1978) or by Yamaguti (1961) the nematode is defined to the genus Elaphostrongylus.

\section{DISCUSSION}

In 1930 a nematode about $5 \mathrm{~cm}$ long was observed in the fasciae beneath the M. latissimus dorsi of a Scottish deer (Cervus elaphus L.) by Miller (1931). The nematode was given the name Elaphostrongylus cervi by Cameron (1931). Later two more species have been described, Elaphostrongylus panticola( Liubimov 1945) from red deer in Asia (Cervus elaphus sibiricus) and Elaphostrongylus rangiferi (Mitskevich 1958) from reindeer (Rangifer tarandus tarandus L.).

The taxonomical position of these nematodes is, however, not clarified. Kutzer \& Prosl (1975) stated Elaphostrongylus panticola to be synonymous with Elaphostrongylus cervi. They also considered Elaphostrongylus rangiferi to be synonymous with Elaphostrongylus cervi. Pryadko \& Boev (1971) considered Elaphostrongylus cervi, Elaphostrongylus panticola and Elaphostrongylus rangiferi to be subspecies. The dividing into species of the genus Elaphostrongylus has apparently been more related to the different cervidae hosts than to differences in the morphology. This division into species has been questioned (Lankester $\&$ Northcott 1979). It the present investigation the identity of Elaphostrongylus is so far not taxonomically clarified.

Elaphostrongylus spp. have been described in various cervidae of the world, as red deer (Cervus elaphus L.) (Cameron 1931, Kutzer \& Porsl 1975, Mason et al. 1976, Borg 1979, Helle 1980, Watson 1983), wapiti (Cervus elaphus canadensis) (Mason 1976), reindeer (Rangifer tarandus tarandus L.) (Roneus $\&$ Nordkvist 1962, Nordkvist et al. 1962, Bakken \& Sparboe 1973, Kummeneje 1974), fallow deer (Dama dama L.) (Sugar 1978), 
roe deer (Capreolus capreolus L.) (Nilsson 1971, Borg 1975, Kutzer \& Prosl 1975, Sugar 1978) and moose (Alces alces L.) (Nilsson 1971, Borg 1975, Holt 1982, Halvorsen \& Wissler 1983, Roneus et al. 1984).

In some reports Elaphostrongylus cervi is considered rather apatogen causing only minor lesions (Mason 1976, Sutherland 1976, Prosl \& Kutzer 1980).

In Austrian red deer, despite the occurrence of Elaphostrongylus cervi in the subdural and subarachnoidal space, Prosl $\&$ Kutzer (1980) did not find any histopathological lesions. The only lesions found were connected with larvae of Elaphostrongylus cervi in the lungs.

Sutherland (1976) described gross and histopathological lesions in the connective tissues, lymph nodes and lungs. These lesions varied, from mild infiltrations of eosinophils to granulomas with a central necrosis. In the lungs larvae were observed to produce a diffuse interstitial pneumonia, consolidation and focal emphysema. Lesions in the central nervous system were not observed.

Clinical disease and pathological lesions in connection with Elaphostrongylus sp. infections, however, have been reported by several authors.

Schwangart (1940) found Elaphostrongylus nematodes in the brain and spinal cord of a paralysed red deer.

Lankester (1977) reported of an experimental infection in moose with larvae of Elaphostrongylus cervi obtained from caribou. Neurological signs with pronounced weakness affecting the hindlimbs were seen. At necropsy adult Elaphostrongylus nematodes were found associated with the brain and spinal cord. Lankester states that the tissue damage caused by the parasites in the central nervous system was undoubtedly responsible, at least in part, for the pronounced neurological signs exhibited.

In 1979 Borg described a case of paralysed hindquarters in a red deer calf from a zoo in Sweden. The postmortal examination revealed the presence of Elaphostrongylus cervi in the region of the cerebellum.

Watson (1983) reported on clinical signs i.e. exercise intolerance, blindness, hindlimb incoordination and occasional nervous disorder in 17 red deer infected with larvae of Elaphostrongylus cervi. He also noticed clinical disease associated with verminous pneumonia and a severe pulmonary haemorrhage. 


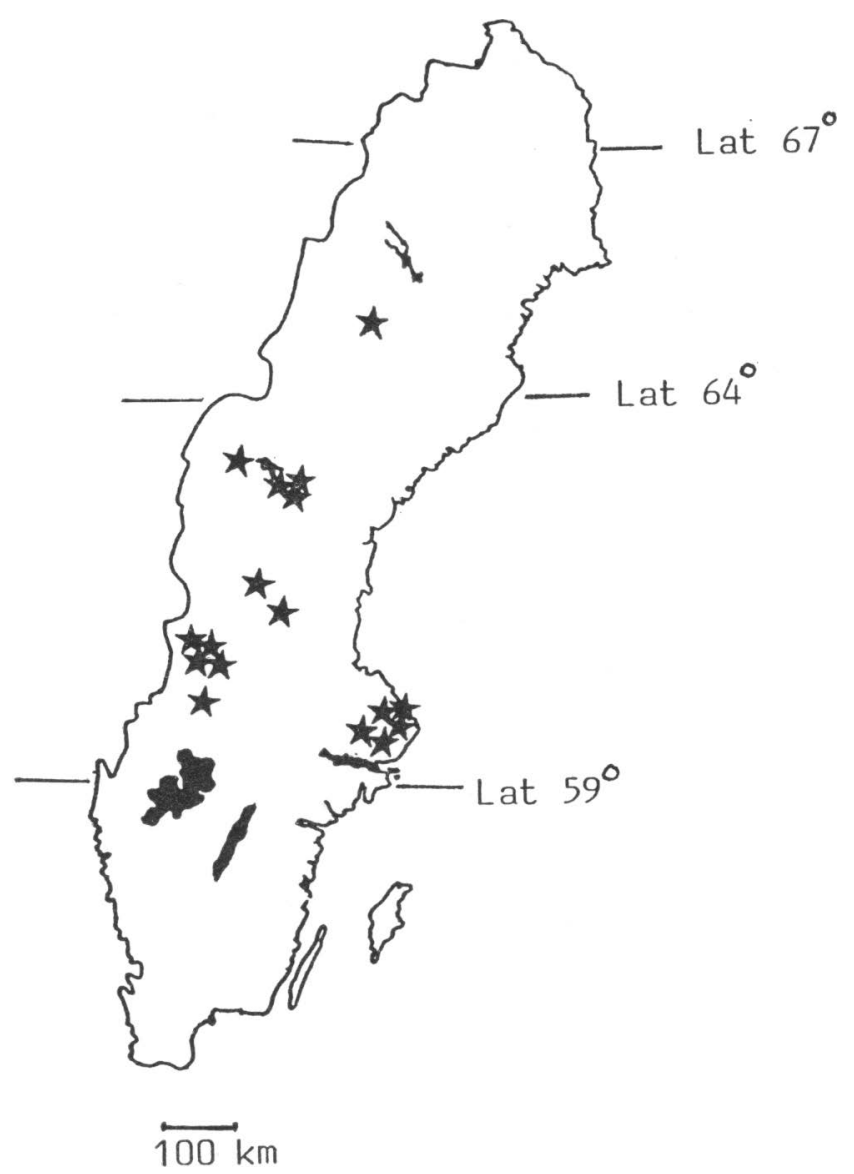

Figure 9. Map of Sweden. The locations of findings of moose infected with Elaphostrongylus sp. are indicated.

In reindeer Elaphostrongylus rangiferi is well known to cause morbidity as well as mortality characterized by central and peripheral nervous lesions and pneumonia (Roneus \& Nordkvist 1962, Bakken \& Sparboe 1973, Kummeneje 1974).

The parasites are established in large parts of different reindeer populations, sometimes giving rise to a considerable mortality but sometimes obviously not resulting in an increased morbidity or mortality. In reindeer mostly calves are clinically affected although most adults are infected (Nordkvist et al. 1962, Bakken \& Sparboe 1973, Kummeneje 1974).

Also in our material young animals seem to be moore prone to suffer from Elaphostrongylus infections (Table 2). 
In the present investigation lesions were found similar to those described by Lankester (1977).

Inflammatory lesions were found to be more frequently connected with the presence of eggs than with larvae or adult nematodes. The eggs also produced multiple granulomas, with large amounts of mononuclear and epitheloid cells, in the leptomeninges and in loose connective tissue between nerve bundles.

Larvae were often found in close connection with eggs. Sometimes eggs, remains of eggs and larvae were found within the same granulomas. This indicates that eggs of this particular species of Elaphostrongylus do hatch in loose connective tissue as reported by Vsevolodov \& Pryadko (1964) and Barus \& Blazek (1973).

The finding of hemosiderin-like granulae in this investigation correspond to reports on red deer infected with Elaphostrongylus cervi (Dykova' 1969). Probably these detritus masses are the excrements of the nematode.

It is indicated, from the lesions found and the preponderance of emaciation among the infested animals, that neurological disorder due to elaphostronglyolsis could be the cause of emaciation and death of moose.

The present investigation and earlier observations (Roneus et al. 1984, Nilsson in manuscript) indicate that Elaphostrongylus sp. is widely distributed in Swedish moose population (Fig. 10). However, the observations are still few and the infection rate is thus yet unknown.

\section{ACKNOWLEDGEMENTS}

The excellent technical assistance by Ingegerd Forssell is gratefully acknowledged. Magnus Nordkvist is gratefully thanked for valuable discussions.

\section{REFERENCES}

Anderson, $R$. C.: C.I.H. keys to the nematode parasites of vertebrates. No 5. Key to the genera of the superfamily Metastrongyloidea. Commonwealth Agricultural Bureau, Farnham Royal, Bucks, England 1978. $40 \mathrm{pp}$.

Bakken, G. \& O. Sparboe: Elaphostrongylose hos rein. (Elaphostrongylosis in reindeer). Nord. Vet.-Med. 1973, 25, 202-210.

Barus, V.\& K. Blazek: Reports on the findings of larvae nematodes Elaphostrongylus cervi (protostrongyloidea) in the cranial cavity of a stag. Folia Parasit. (Prague) 1973, 20, 279—280. 
Borg, K.: Viltsjukdomar. (Wildlife Diseases). Karl Borg och LTs förlag 1975, $191 \mathrm{pp}$.

Borg, K.: Symptome der Kreuzlähme (Schlenderkrankheiten) bei Elaphostrongylus befalls des Kleinhirsch bei einem Rotwildkalb. (Symptoms of a lumbar paralysis (Kreuzlähme) in a red deer calf on the accasion of Elaphostrongylus infestation of the cerebellum). Z. Jagdwiss. 1979, 25, 237-238.

Cameron, T. W. M.: On two new species of nematodes from the Scottish red deer. J. Helminthol. 1931, 9, 213-216.

Dykova', I.: Elaphostrongylus cervi Cameron, 1931, in the central nervous system of red deer (Cervus elaphus). Folia Parasit. (Prague) 1969, 16, 74.

Halvorsen, O. \& K. Wissler: Elaphostrongylus sp. (Nematoda, Protostrongylidae) and other helminths in faeces of moose (Alces alces (L.)) in north Norway. Fauna norv. Ser. A, 1983, 4, 3740.

Helle, O.: Elaphostrongylus cervi Cameron, 1931, hos hjort (Cervus elaphus) i Norge. (Elaphostrongylus cervi Cameron, 1931, in red deer (Cervus elaphus) in Norway). Norsk Veterinærtidskrift 1980, 92, 677-678.

Holt, G.: Påvisning av elaphostrongylose hos elg i Sör-Norge gir grunn til en viss engstelse. (Finding of elaphostrongylosis in moose in Southern Norway gives cause to certain worries). Jakt-, FiskeFriluftsliv 1982, 111 (9), 33-34, 66.

Kummeneje, K.: Encephalomyelitis and neuritis in acute cerebrospinal nematodiasis in reindeer calves. Nord. Vet.-Med. 1974, $26,456-458$.

Kutzer, E. \& H. Prosl: Zur Kenntnis von Elaphostrongylus cervi Cameron, 1931. 1. Morphologie und Diagnose. (Contribution to the knowledge of Elaphostrongylus cervi Cameron, 1931). Wien. tierärztl. Mschr. 1975, 62, 258-266.

Lankester, M. W.: Neurologic disease in moose caused by Elaphostrongylus cervi Cameron, 1931, from caribou. Proceedings of the 13th Annual North American Moose Conference and Workshop. Jasper, Alberta 1977, 177-190.

Lankester, M. W. \& T. H. Northcott: Elaphostrongylus cervi Cameron, 1931, (Nematoda: Metastrongyloidea) in caribou (Rangifer tarandus caribou) of Newfoundland. Canad. J. Zool. 57, 13841392.

Liubimov, M. P.: New worm diseases of the brain of deer with unossified antlers. (In Russian). Sbornik nauchnoissledovatel' skikh rabot (Laboratoriya sovkhozov SSR) 1945, 1, 225-232.

Mason, P. C. \& H. J. F. McAllum: Dictyocaulus viviparus and Elaphostrongylus cervi in wapiti. N. Z. Vet. J. 1976, 24, 23.

Mason, P. C., N. R. Kiddey, R. J. Sutherland, D. M. Rutherford \& A. G. Green: Elaphostrongylus cervi in red deer. N. Z. Vet. J. 1976, $24,22-23$. 
Mitskevich, V. I.: The elucidation of the life-cycle of the nematode Elaphostrongylus rangiferi sp. nov. from reindeer (In Russian). Dokl. Akad. Nauk. SSSR 1958, 119, 621-624.

Nilsson, O.: The inter-relationship of endoparasites in wild cervids (Capreolus capreolus L. and Alces alces L.) and domestic ruminants in Sweden. Acta vet. scand. 1971, 12, 36-68.

Nordkvist, M., O. Roneus \& O. Nilsson: Further observations on cerebrospinal nematodiasis (Elaphostrongylus rangiferi) in reindeer. Separatum from 9th Nordic. Vet. Congress. Sect. B no. 4, 1963.

Prosl, H. \& E. Kutzer: Pathology of Elaphostrongylus infestation of red deer (Cervus elaphus). (In German). Mh. Vet.-Med. 1980, $35,151-153$.

Pryadko, E. I. \& S. N. Boev: Systematics, phylogeny and evolution of Elaphostrongylinae nematodes of deer. (In Russian). Izdatel'stvo Akad. Nauk Kazakhskoi SSR, Alma-Ata 1971, 5, 41-48.

Roneus, O. \& M. Nordkvist: Cerebrospinal and muscular nematodiasis (Elaphostrongylus rangiferi) in Swedish reindeer. Acta vet. scand. 1966, 3, 201-225.

Roneus, O., N.-G. Nilsson \& C. Rehbinder: Onchocerca lesions in moose (Alces alces L.). Nord. Vet.-Med. 1984, 36, 367-370.

Schwangart, E.: Über die endemische Parese des Rotwildes und Tuberkulose beim Reh. (On the endemic paresis in red deer and tuberculosis in roe deer). Berl. Münch. tierärztl. Wschr. 1940, $6,61$.

Sugar, L.: On the nematode infestation of wild ruminants in Hungary. (In Hungarian). Parasitol. Hung. 1978, 11, 146-148.

Sutherland, R. J.: Elaphostrongylus cervi in cervids in New Zealand. I. The gross and histological lesions in red deer (Cervus elaphus). N. Z. Vet. J. 1976, 24, 263-266.

Watson, T. G.: Elaphostrongylus cervi Cameron in Canada and New Zealand: a historical overview. N. Z. J. Zool. 1980, 7, 604.

Watson, T. G.: Some clinical and parasitological features of Elaphostrongylus cervi infections in Cervus elaphus. N. Z. J. Zool. 1983, $10,129$.

Wissler, K. \& O. Halvorsen: Infection of reindeer with Elaphostrongylus rangiferi (Nematoda, Metastrongyloidea) in relation to age and season. Norw. J. Zool. 1976, 24, 462-463.

Vsevolodov, B. P. \& E. I. Pryadko: In Parasites of Farm animals of Kazakhstan (In Russian) Isdatel Akad. Nauk Kazakhstan SSR. Alma-Ata. 1964, p. 3-71.

Yamaguti, S.: System Helminthum. Vol. 3. Nematodes part 5. 1961. $348 \mathrm{pp}$. 


\section{SAMMANFATTNING}

Nervvävnadsskador orsakade av elaphostrongylos hos viltlevande älg i Sverige.

Under de 5 första månaderna 1985 inkom 35 älgar till Statens Veterinärmedicinska Anstalt, Uppsala, för obduktion. Hos 17 av dessa $(49 \%)$ påvisades infektion med Elaphostrongylus sp.

Nematoderna påträffades epiduralt på ryggmärg och hjärna, runt och $\mathrm{i}$ ischiadicusnerver samt vid muskelfascier. Predilektionsställen var i anslutning till cauda equina samt intill fascier för pectoral-, gracilis- och sartoriemusklerna. Av de infekterade djuren utgjordes huvuddelen av kalvar. Båda könen var likvärdigt representerade. De patologiska fynden karakteriserades av fokala blödningar och ödem. Förändringarna förelåg i muskelfascier samt i hjärnans och ryggmärgens leptomeninger. De histologiska fynden utgjordes av infiltrat med huvudsakligen lymfocyter och plasmaceller, samt adulta nematoder, larver och ägg. Degenerativa förändringar, som nådde in till epi- och perineurium, påvisades i perifera nervers rötter. I ett fall nådde den inflammatoriska processen in $i$ ischiadicusnervens endoneurium och $i$ ett annat fall in $i$ ett ganglion. Dessutom sågs fall med mild glios i storhjärnan. Det inflammatoriska svaret gentemot parasiten var främst riktat mot äggen. I lucker bindväv intill nervvävnad i centrala nervsystemet påvisades larver $\mathrm{i}$ anslutning till ägg och rester av kläckta ägg, vilket indikerar att ägg kläckes där.

Denna undersökning visar att naturliga infektioner med Elaphostrongylus sp. förekommer hos vild älg och kan förorsaka patologiska förändringar i stora perifera nerver och centrala nervsystemet.

(Received April 10, 1986).

Reprints may be requested from: M. Steen, the National Veterinary Institute, P. O. Box 7073, S-750 07 Uppsala, Sweden. 